\title{
Мониторинг технического состояния композитных изделий на основе встраиваемой интеллектуальной волоконно-оптической сенсорики
}

\section{Monitoring the technical health of composite structural elements using the integrated intellectual optical fiber sensor system}

\section{Г. Я. Буймистрюк}

ОКБ Московского завода «ФИЗПРИБОР»

г. Санкт-Петербург, Россия

\section{G. Y. Buymistriuk}

Design Bureau of the Moscow Plant "FIZPRIBOR"

St. Petersburg, Russia

Поступила в редакцию 16.01.2020, принята к печати 23.01.2020

\section{Абстракт}

Рассмотрены технологические и метрологические особенности встраиваемой сенсорики измерительных систем неразрушающего контроля и мониторинга технического состояния композитных изделий. Показаны технологические возможности аддитивных и молекулярных технологий с малоразмерными соединениями ввода/вывода для надёжного встраивания волоконно-оптических сенсоров в композитные изделия. Рассмотрены возможности повышения качества неразрушающего контроля состояния методами сенсорного слияния информации и метрологического самоконтроля встроенной волоконно-оптической сенсорной сети путем интеллектуализации датчиков и нейросетевых методов их самокалибровки в процессе эксплуатации композитных изделий.

\section{Abstract}

In the present paper, important features of the fabrication and exploitation of in-situ systems of non-destructive controlling and health monitoring of composite structural elements are discussed. The application of Additive Manufacturing and Molecular Technologies together with small-size input/output connectors allows integrating of sensors into the composite structures. There are also discussed the ways of improving the quality of non-destructive testing of the structural elements by using the method of a sensory combination of the generating information and metrological self-control. This is achieved by using intellectual sensors and neural-network methods of their self-calibration during service time of the composite structural elements.

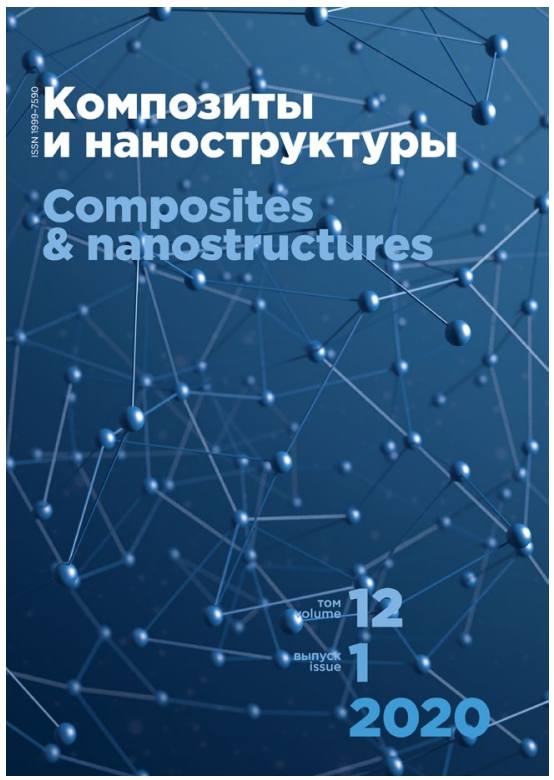

